\title{
Evaluating Alternative Measures of Institutional Protection of Private Property and Their Relative Ability to Predict Economic Development
}

\section{Daniel L. Bennett \\ Patrick Henry College}

Hugo J. Faria

University of Miami

James D. Gwartney

Florida State University

\section{Daniel R. Morales}

Instituto Dominicano de Evaluación e Investigación de la Calidad Educativa (IDEICE)

\begin{abstract}
A growing body of research suggests that private property rights are an important determinant of economic development. This paper assesses five commonly used measures of property rights and their relative ability to predict economic development. The International Country Risk Guide risk of expropriation and World Governance Indicators rule of law measures, as well as property rights indices from the Fraser Institute and Heritage Foundation, are all positively and robustly associated with GDP per capita. Polity IV's executive constraints measure has a statistically and economically weaker impact. This paper also addresses the methodological strengths and weaknesses of each measure to guide researchers in selecting an appropriate measure for empirical studies.
\end{abstract}

JEL Codes: K11, O17, P14

Keywords: comparative economic development, economic freedom, legal institutions, private property rights, rule of law, institutional measurement methodology

\section{Introduction}

While scholars appear to have reached a consensus that North (1990) was correct in his assertion that a society's institutions define the incentive structure that economic actors face and are therefore key 
determinants of economic performance, there is less of a consensus regarding which institutions are most important for the development process. Some authors argue that democratic political institutions drive economic development (e.g., Acemoglu et al. 2014; Persson and Tabellini 2003; Rodrik 2000), while others stress that economic and legal institutions are essential in the development process (e.g., Barro 1996; Gwartney, Holcombe, and Lawson 2006).

A multitude of institutional measures are now at researchers' disposal and have been used in empirical research on institutions and economic performance. Although there is some debate regarding the specific institutions that matter most for economic development, there is considerable agreement that the protection of private property is necessary for sustained, long-run economic development.

Secure private property rights incentivize the efficient use of economic resources by enabling economic actors to engage in rational economic calculus. When property rights are well-defined and secure, economic actors can internalize the full economic costs and reap the full economic benefits or losses of their decisions. Actors can engage in profit and loss accounting and market prices are a reliable indicator of the relative value of a resource's alternative uses. The market process directs resources away from unprofitable activities and into more profitable and hence productive ventures, promoting economic growth.

Without secure property rights, prices are distorted and fail to convey accurate information through markets in a timely manner to signal the relative profitability of alternative uses of a given resource. In addition, insecure property rights increase the attractiveness of short-term investments relative to longer-term and potentially more productive investments because the higher risk of expropriation reduces the latter's expected returns. Insecure property rights therefore lead to less productive employment of resources and less innovation, stymieing economic development.

Several studies show that institutions that protect private property rights are a fundamental cause of economic development (Acemoglu, Johnson, and Robinson 2001; Bennett et al. 2016; Faria and Montesino 2009; Gwartney, Holcombe, and Lawson 2006; Hall and Jones 1999; Knack and Keefer 1995; Rodrick, Subramanian, and Trebbi 2004). Although a growing body of literature supports the notion that institutional protection of private property rights is vital for sustainable economic development, researchers continue to use alternative measures for this variable. A growing body of literature 
also exists that examines the methodology of institutional measurement (Berggren, Bergh, and Bjørnskov 2012; Feld and Voigt 2003; Langbein and Knack 2010; Munck and Verkuilen 2002; Voigt 2012, 2013). This paper assesses the methodological strengths and weaknesses of five commonly used measures of property rights, as well as their relative ability to predict the level of economic development.

The empirical results suggest that the International Country Risk Guide risk of expropriation, Fraser Institute and Heritage Foundation property rights indices, and World Governance Indicator rule of law index measures are all robustly correlated with the level of economic development, and the estimated effects are quantitatively similar across measures. Meanwhile, the Polity IV executive constraints measure has a much smaller and less robust impact on economic development. The methodological analysis suggests that the executive constraints measure may, to a degree, reflect limitations on the political executive's ability to engage in predatory extraction of private property, but it does not reflect similar constraints placed on other governmental bodies or private actors. It is therefore, at best, an incomplete and weak proxy for the protection of private property rights from public predation. The other four measures are based on a strong theoretical concept of property rights, potentially explaining their robust correlation with economic development. This paper also assesses several other methodological features of the measures, including the aggregation method, data objectivity, whether the indicators measure de facto or de jure institutions, the public availability of the data, and the indicators' transparency and replicability.

Section 2 recaps the institutional measurement methodology literature, and section 3 analyzes the five measures of institutional protections of private property. Section 4 describes additional data used in this study. Section 5 presents the empirical results, and section 6 concludes.

\section{Institutional Measurement and Methodology}

Social scientists, policymakers, and development agencies are increasingly concerned with the importance of institutions for economic development and other socioeconomic concerns, as evidenced by the surge of research estimating the quantitative causal impact of institutions on a variety of outcomes. Munck and Verkuilen (2002, p. 5) indicate that while "this is a welcome development ... 
quantitative researchers have paid sparse attention to the quality of data ... that they analyze." Voigt $(2013$, p. 2) adds that "if one wants to show that institutions matter ... one needs a reliable way to identify and measure them." A growing body of literature examines institutional measurement methodology. Five issues this literature has raised are relevant to the current study.

First, the literature stresses the importance of linking theory to the measurement of institutions. Voigt (2013, p. 9), for instance indicates that the "attempt to measure institutions needs to be driven by an underlying theory." Munck and Verkuilen (2002, p. 7) suggest that the first step in constructing an institutional measure is to identify "attributes that are constitutive of the concept under consideration ... which amounts to a specification of the meaning of the concept." Langbein and Knack (2010, p. 351) add that indicators of an abstract concept such as an institution should "systemically and reliably relate to the concept." The degree to which an institutional indicator measures the concept it is intended to measure reflects the indicator's validity (Munck and Verkuilen 2002).

Second, the aggregation of variables into an institutional indicator is also a concern. Munck and Verkuilen (2002) outline a methodology for aggregating institutional indicators that follows from the conceptualization step described previously. A highly abstract institutional concept should be broken down into subsequently lower levels of abstraction that delineate certain attributes and components of the metaconcept. The components are measurable and can be aggregated to measure the higher order attributes. The attributes can, in turn, be aggregated to generate a measure of the highly abstract concept. $^{1}$

The authors stress the importance of selecting multiple components drawn from multiple sources to reduce the potential for biases associated with a single variable. The aggregation method should, to the extent possible, be driven by theory concerning the relationship between the various components and attributes of an institutional concept, and should be done in such a way as to prevent the loss of useful information. Voigt $(2013$, p. 2), on the other hand, argues that "measures of institutions should refer to specific

\footnotetext{
${ }^{1}$ As an example, the concept of democracy is characterized by the attributes of contestation and participation. The contestation attribute is characterized by components such as the right to form political parties and freedom of the press, while participation is characterized by components such as suffrage and fairness in the voting process (Munck and Verkuilen 2002).
} 
institutions because aggregate measures ... are too broad and fuzzy to contain meaningful information." Studies by Berggren, Bergh, and Bjørnskov (2012) and Langbein and Knack (2010), respectively, examine the International Country Risk Guide and World Governance Indicators data, two common composite institutional indices.

Third is the issue of objective versus subjective variables in the construction of institutional indicators. Objective variables are based on underlying objective data, while subjective variables are based largely on survey data that capture subjective evaluations of survey respondents that may be systematically biased by the respondents' perception of how the institutional indicator they are being asked to evaluate affects some other observable measure of the prevailing economic, political, and/or social conditions. Although institutional indicators derived from objective data are generally preferable, data availability is often limited to subjective measures, and subjective indicators may provide useful information that is difficult to ascertain from objective measures (Langbein and Knack 2010; Voigt 2013).

Fourth is the issue of de facto versus de jure institutional measures. Voigt (2013) indicates that effort should be made to measure both the legal and practical specifications of an institution because there is interest in studying the effects of both. Feld and Voigt (2003), for instance, provide evidence that economic growth is affected by de facto but not de jure judicial independence. The interaction of de facto and de jure institutions may also be important. For example, Justesen (2014), Justesen and Kurrild-Klitgaard (2013), and Voigt and Gutmann (2013) provide evidence that the interaction of de facto legal and de jure political institutions promotes growth.

Lastly, this literature suggests that the data used to derive an institutional measure should be made publicly available and the methodology transparent for replicability. In addition, these two conditions permit researchers to derive customizable institutional indicators to allow for testing of the robustness of results (Munck and Verkuilen 2002; Langbein and Knack 2010).

\section{Measures of Institutional Protection of Private Property Rights}

The effective protection of private property requires a set of mutually reinforcing de facto and de jure institutions. This analysis, therefore, considers property rights measures that contain multiple 
components. This section briefly describes and assesses five commonly used measures of property rights:

- International Country Risk Guide: risk of expropriation (ExpropriationRisk)

- Polity IV: executive constraints (ExecutiveConstraint)

- Fraser Institute: property rights index (FraserPRIndex)

- Heritage Foundation: property rights index (HeritagePRIndex)

- World Governance Indicators: rule of law index (RuleLaw)

Each measure is assessed according to the criteria described in section 2. ${ }^{2}$ Table 1 provides simple correlations of the five measures for the entire sample. All of the measures have correlations above 0.8 with the exception of ExecutiveConstraint, which has a correlation of 0.52 to 0.63 with the other four measures. ${ }^{3}$

Table 1. Correlation Matrix

\begin{tabular}{llllll}
\hline & $\begin{array}{l}\text { Expropriation } \\
\text { Risk }\end{array}$ & $\begin{array}{l}\text { Executive } \\
\text { Constraint }\end{array}$ & $\begin{array}{l}\text { Fraser } \\
\text { PRIndex }\end{array}$ & $\begin{array}{l}\text { Heritage } \\
\text { PRIndex }\end{array}$ & $\begin{array}{l}\text { Rule } \\
\text { Law }\end{array}$ \\
ExpropriationRisk & 1.00 & & & & \\
ExecutiveConstraint & 0.57 & 1.00 & & & \\
FraserPRIndex & 0.87 & 0.52 & 1.00 & & \\
HeritagePRIndex & 0.80 & 0.59 & 0.85 & 1.00 & \\
RuleLaw & 0.83 & 0.63 & 0.93 & 0.90 & 1.00 \\
\hline
\end{tabular}

2 The six criteria are (1) the theoretical basis for the measure; (2) the aggregation process used; (3) the objectivity of data used in its construction; (4) whether the measures reflect de facto or de jure institutions, or a combination of the two; (5) whether data are publicly available; and (6) methodological transparency and replicability. Table 1 in Bennett et al. (2015) summarizes the methodological assessment of the five measures.

${ }^{3}$ Similar but slightly smaller correlations exist for the subsample of countries with GDP per capita above the median. For the subsample of countries below the median, the correlation between the ExpropriationRisk, FraserPRIndex, HeritagePRIndex, and RuleLaw measures ranges from 0.45 to 0.7 , while ExecutiveConstraint has a correlation of 0.36 or less with the four other measures. For the upper quartile of countries, all five measures have cross-correlations above 0.49; however, the correlations for the bottom quartile are significantly lower, although FraserPRIndex has a correlation of at least 0.64 with all but ExecutiveConstraint. 


\section{A. International Country Risk Guide: Risk of Expropriation}

Risk of expropriation (ExpropriationRisk) provides a subjective assessment of the risk in a country for outright confiscation and forced nationalization of private foreign investment and property. ${ }^{4}$ ExpropriationRisk has been used as a measure of private property rights in numerous scholarly articles and is commonly found to be positively associated with economic performance (Acemoglu and Johnson 2005; Acemoglu, Robinson, and Johnson 2001; Knack and Keefer 1995; Hall and Jones 1999; Hall, Sobel, and Crowley 2010).

The measure is based on expert opinions and analysis of economic and political data by the Political Risk Group, a private international risk service firm, as part of its International Country Risk Guide. ExpropriationRisk is measured on a $0-10$ scale, with higher values reflecting a lower risk of expropriation by the state, and hence more secure de facto private property rights. The methodology used to determine the variable is opaque, such that the measure is not replicable and it is not possible to derive alternative measures. Glaeser et al. (2004, p. 276) question its validity as a measure of institutions, arguing that it reflects economic or policy outcomes rather than "permanent rules, procedures, or norms supplying checks and balances on the sovereign."

ExpropriationRisk represents the average score over the period 1985-1995, as used by Acemoglu, Johnson, and Robinson (2001) and Acemoglu and Johnson (2005). Because the data are sold commercially and are not publicly available, access to more recent measures was unavailable for the current study.

\section{B. Polity IV: Executive Constraints}

The executive constraints variable (ExecutiveConstraint) is part of the Center for Systemic Peace's Polity IV dataset. ${ }^{5}$ Countries receive a categorical score between one and seven that increases as the political executive's decision-making capacity is constrained by the political system's checks and balances. The assessments are subjective and based on expert evaluations of historical monographs and other sources (Marshall, Gurr, and Jaggers 2013). The methodology is therefore somewhat ambiguous and the measure is not replicable.

\footnotetext{
${ }^{4}$ Data available annually for up to 140 countries over the period 1984-2013.

${ }^{5}$ Data available annually for up to 174 countries beginning in 1800 , or shortly after a country became politically independent.
} 
ExecutiveConstraint is often used as a measure of property rights institutions and is commonly found to be a positive determinant of economic performance (e.g., Acemoglu, Johnson, and Robinson 2001, 2005). Acemoglu and Johnson (2005) say it is their preferred measure of property rights institutions and argue that it corresponds to procedural rules that constrain state action such that it serves as a proxy for limitations on the political executive's ability to expropriate private property. Glaeser et al. (2004), citing volatility in the measure for a number of countries, argue that ExecutiveConstraint provides an assessment of recent electoral outcomes rather than actual procedures or rules constraining government. We use the average over the period 1985-2010 in the analysis. ${ }^{6}$

\section{Fraser Institute: Property Rights Index}

The Fraser Institute publishes the Economic Freedom of the World (EFW) index. ${ }^{7}$ It is derived from publically available data and the methodology is highly transparent, such that it is replicable and researchers can easily construct alternative indicators. Although some variables are based on subjective external expert assessments, the authors give preference to objective data measures in computing the index (Gwartney, Lawson, and Hall, 2013), making it desirable as a broad measure of mutually reinforcing economic institutions and policies (Acemoglu, Johnson, and Robinson 2001). The EFW index has consistently been found to be a positive determinant of growth and development (e.g., Bennett et al. 2016; Hall and Lawson 2014). ${ }^{8}$

We use the area two index (FraserPRIndex), which measures how well the rule of law protects persons and their rightfully acquired property. It contains nine mutually reinforcing components, some of which are de facto indicators and others of which are de jure indicators. We use the average chain-linked measure over the period 1985-2010.

\footnotetext{
${ }^{6}$ A country must have observations available for at least sixteen of twenty-six years; otherwise, it is coded as missing. Some country-year observations are coded as -66 , -77 , or -88 , reflecting periods of political transition. These values are recoded as missing.

${ }^{7}$ Data available quinquennially over the period 1970-2000 and annually thereafter for up to 152 countries.

${ }^{8}$ Because most readers are familiar with the EFW data, information about its components and aggregation method is omitted. See Gwartney, Lawson, and Hall (2013) for more information.

9 The nine components are judicial independence, impartial courts, protection of property rights, military interference in the rule of law and politics, integrity of the legal system, legal enforcement of contracts, regulatory restrictions on the sale of
} 


\section{Heritage Foundation: Property Rights Index}

The Heritage Foundation, in partnership with the Wall Street Journal, publishes the Index of Economic Freedom. ${ }^{10}$ Comprised of ten components, it measures the degree to which a country's institutions and policies are nondiscriminatory, empower the individual, and promote open competition. ${ }^{11}$ Each component represents one of four pillars of the economic environment over which governments exert policy control: rule of law, government size, regulatory efficiency, and market openness. As with the Fraser Institute index, the Heritage index gives preference to objective data measures, but some measures are based on subjective assessments by the index's authors. Each component is assigned a score between 0 and 100, with a higher score indicating greater freedom (Miller, Kim, and Holmes 2014).

The property rights component, a qualitative assessment by the index authors of how well a country's legal framework allows individuals to freely accumulate private property, secured by clear laws that the government enforces effectively, is used in this study (HeritagePRIndex). The index also accounts for judicial independence, corruption within the judiciary, and the enforceability of contracts. Each country is assigned a categorical score between 0 and 100 that is based on these parameters. ${ }^{12}$ Although the methodology is transparent concerning the categorical scores and the transformed data are publicly available, data for the underlying variables and/or sources are not available and the methodology is somewhat ambiguous. Thus, it is not possible to reproduce the index

real property, reliability of police, and business costs of crime. Each is weighted equally.

${ }^{10}$ The data are available annually over the period 1995-2014 for up to 186 countries.

11 The ten components are property rights, freedom from corruption, fiscal freedom, government spending, business freedom, labor freedom, monetary freedom, trade freedom, investment freedom, and financial freedom.

12 As an illustration, a country receives a score of 100 if the authors deem that the government guarantees private property, the courts enforce contracts efficiently and quickly, the judicial system punishes those who unlawfully confiscate private property, and corruption and state expropriation are nonexistent. A country receives a score of 50 if the court system is inefficient and subject to delays, corruption is present, other branches of government may influence the judiciary, and expropriation is possible but rare. A country receives a zero if all property belongs to the state, people have no legal recourse over others and lack access to the court system, and corruption is endemic. 
and the construction of alternative measures. We use the average measure over the period 1995-2010.

\section{E. World Governance Indicators: Rule of Law Index}

The World Governance Indicators (WGI) dataset is a widely used measure of institutional quality. It contains six aggregate dimensions of governance and is comprised of data from thirty-two different sources that are aggregated using a three-step process. ${ }^{13}$ First, data points from each source are assigned to one of the six dimensions. Next, each datum is initially converted to a $0-1$ scale, with higher scores reflecting better institutions. Last, an unobserved components model is used to construct a weighted average of the individual indicators for each source, with weights reflecting the pattern of correlation among data sources. The resulting estimates for each dimension reflect a standard normal distribution with mean 0 and standard deviation 1, and range from approximately -2.5 to 2.5 , with higher values reflecting better institutional quality. The index's authors argue that this process enhances the comparability of units (Kaufmann, Kraay, and Mastruzzi 2010). ${ }^{14}$

The WGI data have been criticized for several reasons, including the public unavailability of the underlying variable data. Its authors have subsequently made the data available, making replicability and construction of alternative measures possible. The indicators are not chain-linked, so the comparability of observations for a given country over periods is questionable. Many data sources used to derive it are based largely on subjective surveys of subject matter and country experts, such that the validity of the measures has been questioned (Glaeser et al. 2004; Landbeing and Knack 2010). Thomas (2010, p. 50), for instance, argues that the "WGI claim to measure governance ... [but] represent a complex atheoretical and as yet poorly articulated hypothesis for which no evidence has been advanced."

We use the average rule of law (RuleLaw) area measure over the period 1996-2010. ${ }^{15}$ RuleLaw purports to measure "perceptions of the extent to which agents have confidence in and abide by the rules

\footnotetext{
13 The six dimensions are voice and accountability, political stability and absence of violence, government effectiveness, regulatory quality, rule of law, and control of corruption.

14 The data are available biannually over the period 1996-2002, and annually over the period 2002-2013 for up to 215 countries.

15 A country must have observations available for at least five of the eight biannual periods; otherwise, it is coded as missing.
} 
of society, and in particular the quality of contract enforcement, property rights, the police, and the courts, as well as the likelihood of crime and violence" (Kaufmann, Kraay, and Mastruzzi 2010, p. 4). RuleLaw accounts for many of the factors that theory suggests as important for the protection of private property rights, and it has been popularly employed as a measure of property rights institutions in the empirical economic development literature (Auer 2013; Easterly and Levine 2003; Rodrik, Subramanian, and Trebbi 2004).

\section{Additional Data ${ }^{16}$}

This section motivates and describes the data that are used in the empirical analysis in section 5.

\section{A. Economic Development}

The natural log of real GDP per capita in 2010 (GDP2010) measures the level of economic development. Several GDP datasets are available, but we use the 2013 World Bank World Development Indicator measures, primarily because the data are available for the largest number of countries. ${ }^{17}$

\section{B. Geography and Climate}

It has often been argued that geographic and climatic conditions are important determinants of economic development, although there is some debate concerning whether geography and climate impact economic performance directly or through their influence on institutional development (Auer 2013; Easterly and Levine 2003; Rodrik, Subramanian, and Trebbi 2004; Sachs 2003). One line of reasoning suggests that countries located in hot and humid climates are prone to lower labor productivity and a higher prevalence of lifethreatening diseases such as malaria, factors that contribute to underdevelopment. Accordingly, two variables measure a country's disease environment and climate: malaria ecology (Malaria), an index measuring how favorable environmental conditions are for malaria (Sachs 2003), ${ }^{18}$ and the share of the population living in a tropical (Tropics) region (Gallup, Sachs, and Mellinger 1999).

\footnotetext{
${ }^{16}$ A table summarizing all of the variables and sources used in this study is available in Bennett et al. (2015).

${ }^{17}$ The results are robust to various years and alternative GDP datasets. See Bennett et al. (2015) for these results.

18 Malaria ecology is derived from subnational temperature, mosquito abundance, and vector specificity data.
} 
Another geography-based theory of development suggests that it is more costly for countries without access to major water shipping routes and located remotely from world markets to engage in trade, such that their economies are unable to benefit from the division of labor and specialization, leaving them destined for underdevelopment. The current study controls for these potential factors using the share of the population living within $100 \mathrm{~km}$ of the coast (Coast) and the shortest distance by air to one of the three major world markets (MarketDistance) as measures of access to oceanic shipping and world markets, respectively (Gallup, Sachs, and Mellinger 1999). ${ }^{19}$

\section{Population Heterogeneity}

Population heterogeneity is commonly identified as a determinant of both institutional quality and economic performance. Alesina et al. (2003, p. 155) note that population heterogeneity is often associated with geopolitical conflict that "leads to political instability, poor quality of institutions, badly designed economic policy, and disappointing economic performance." Population heterogeneity can occur along many dimensions, such as ethnicity, language, religion, and even genetic diversity. We control for several measures of population heterogeneity.

Following Easterly and Levine (1997), many empirical studies have found a negative and significant relationship between ethnolinguistic fractionalization (ELF) and institutional quality and/or economic performance (Faria and Montesinos 2009; Hall and Jones 1999; Sala-i-Martin, Doppelhofer, and Miller 2004). Accordingly, we control for ELF, an index that approximates the probability that two randomly selected individuals from a population speak the same language or are of the same ethnicity. In addition, three measures of religion are included to account for the potential impact of religious heterogeneity on economic development: CATH80, PROT80, and MUS80 represent the shares of the population that were Catholic, Protestant, and Muslim in 1980, respectively (La Porta et al. 1999).

\footnotetext{
${ }^{19}$ The results are robust to an alternative measure of access to waterways, a dummy variable for landlocked.
} 


\section{Trade Openness}

A large literature suggests that openness to international trade is a key determinant of economic growth (Sachs and Warner 1995; Wacziarg and Welch 2008). We use the sum of imports and exports as share of GDP over the period 2000-2010 as a simple measure of trade openness (Trade). Data are from the World Bank World Development Indicators.

\section{Empirical Results}

This section presents the results from cross-country regressions of GDP per capita in 2010 on institutions and the set of control variables described in section 4 .

\section{A. Main Results}

Table 2 provides the results from OLS regressions of GDP2010 on the five measures of property rights institutions, controlling for trade openness and the set of geography and population heterogeneity variables described in section $4 .{ }^{20}$ The sample is restricted to countries for which all five property rights measures are available to maximize comparability of results. Because the five property rights measures are computed using heterogeneous scales and/or methodologies, standardized coefficients are reported, further enhancing the comparability of the partial effects. ${ }^{21}$ T-statistics pertaining to heteroskedastic-robust standard errors are reported in parentheses.

ExpropriationRisk, FraserPRIndex, HeritagePRIndex, and RuleLaw are all statistically significant at the 1 percent level and exert a similar positive impact on GDP2010, with standardized coefficients ranging from 0.39 to 0.52 . ExecutiveConstraint is also statistically significant, but only at the 5 percent level. With a standardized coefficient of 0.26 , it exerts a noticeably smaller economic impact on GDP2010 than the other four measures.

\footnotetext{
20 There is some concern that institutions and development move simultaneously (Paldam and Gundlach 2008), so effort is taken to measure private property rights over a longer period that predates the observed level of economic development.

21 The standardized coefficients, $\beta$, can be interpreted as follows: a standard deviation increase in property rights is associated with a $\beta$ standard deviation increase in GDP.
} 
Table 2. Main OLS Results

\begin{tabular}{|c|c|c|c|c|c|}
\hline & (1) & (2) & (3) & (4) & (5) \\
\hline ExpropriationRisk & $\begin{array}{l}0.52^{* * *} \\
(5.27)\end{array}$ & & & & \\
\hline ExecutiveConstraint & & $\begin{array}{l}0.26^{* *} \\
(2.55)\end{array}$ & & & \\
\hline FraserPRIndex & & & $\begin{array}{l}0.39 * * * \\
(3.92)\end{array}$ & & \\
\hline HeritagePRIndex & & & & $\begin{array}{l}0.41 \text { *** } \\
(4.92)\end{array}$ & \\
\hline RuleLaw & & & & & $\begin{array}{l}0.44^{* * *} \\
(-4.87)\end{array}$ \\
\hline Coast & $\begin{array}{l}0.14^{* *} \\
(2.53)\end{array}$ & $\begin{array}{l}0.14^{* *} \\
(2.14)\end{array}$ & $\begin{array}{l}0.14^{* *} \\
(2.57)\end{array}$ & $\begin{array}{l}0.11^{*} \\
(1.83)\end{array}$ & $\begin{array}{l}0.11^{*} \\
(-1.91)\end{array}$ \\
\hline MarketDistance & $\begin{array}{l}-0.05 \\
(-0.96)\end{array}$ & $\begin{array}{l}-0.16^{* *} \\
(-2.19)\end{array}$ & $\begin{array}{l}-0.11^{*} \\
(-1.98)\end{array}$ & $\begin{array}{l}-0.16^{* *} \\
(-2.58)\end{array}$ & $\begin{array}{l}-0.13^{* *} \\
(-2.20)\end{array}$ \\
\hline Tropics & $\begin{array}{l}-0.19 * * \\
(-2.04)\end{array}$ & $\begin{array}{l}-0.45^{* * *} \\
(-4.54)\end{array}$ & $\begin{array}{l}-0.28^{* * *} \\
(-2.89)\end{array}$ & $\begin{array}{l}-0.28^{* * *} \\
(-3.13)\end{array}$ & $\begin{array}{l}-0.24^{* *} \\
(-2.59)\end{array}$ \\
\hline Malaria & $\begin{array}{l}-0.12 \\
(-1.22)\end{array}$ & $\begin{array}{l}-0.08 \\
(-1.15)\end{array}$ & $\begin{array}{l}-0.16^{* *} \\
(-2.03)\end{array}$ & $\begin{array}{l}-0.16^{* *} \\
(-2.14)\end{array}$ & $\begin{array}{l}-0.16^{* *} \\
(-2.07)\end{array}$ \\
\hline ELF & $\begin{array}{l}-0.12 \\
(-1.64)\end{array}$ & $\begin{array}{l}-0.02 \\
(-0.22)\end{array}$ & $\begin{array}{l}-0.06 \\
(-0.62)\end{array}$ & $\begin{array}{l}-0.04 \\
(-0.36)\end{array}$ & $\begin{array}{l}-0.02 \\
(-0.19)\end{array}$ \\
\hline CATH80 & $\begin{array}{l}0.11^{*} \\
(1.87)\end{array}$ & $\begin{array}{l}0.05 \\
(0.60)\end{array}$ & $\begin{array}{l}0.10 \\
(1.58)\end{array}$ & $\begin{array}{l}0.05 \\
(0.86)\end{array}$ & $\begin{array}{l}0.09 \\
(-1.45)\end{array}$ \\
\hline MUS80 & $\begin{array}{l}-0.08 \\
(-1.33)\end{array}$ & $\begin{array}{l}-0.18^{* * *} \\
(-2.96)\end{array}$ & $\begin{array}{l}-0.18^{* * *} \\
(-2.80)\end{array}$ & $\begin{array}{l}-0.19^{* * *} \\
(-3.96)\end{array}$ & $\begin{array}{l}-0.17 \text { *** } \\
(-3.31)\end{array}$ \\
\hline PROT80 & $\begin{array}{l}0.00 \\
(0.05)\end{array}$ & $\begin{array}{l}0.03 \\
(0.67)\end{array}$ & $\begin{array}{l}-0.04 \\
(-0.82)\end{array}$ & $\begin{array}{l}-0.05 \\
(-0.98)\end{array}$ & $\begin{array}{l}-0.04 \\
(-0.79)\end{array}$ \\
\hline Trade & $\begin{array}{l}0.07 \\
(1.46)\end{array}$ & $\begin{array}{l}0.11^{*} \\
(1.70)\end{array}$ & $\begin{array}{l}0.06 \\
(1.05)\end{array}$ & $\begin{array}{l}0.05 \\
(0.89)\end{array}$ & $\begin{array}{l}0.05 \\
(-1.01)\end{array}$ \\
\hline Adj.R2 & 0.83 & 0.77 & 0.79 & 0.81 & 0.8 \\
\hline $\mathrm{N}$ & 81 & 81 & 81 & 81 & 81 \\
\hline
\end{tabular}

Note: GDP is the dependent variable in all specifications. Beta coefficients reported. T-stats for standard errors robust to heteroskedasticity in parentheses. Constant term omitted for space. ${ }^{*} \mathrm{p}<0.10,{ }^{* *} \mathrm{p}<0.05,{ }^{* * *} \mathrm{p}<0.01$.

The geography variables have the anticipated signs, with Coast positive and Tropics, Malaria, and MarketDistance negative. Coast and Tropics are always statistically significant at the 10 percent level or better, and MarketDistance is significant at this level in all but one specification. Malaria is statistically significant in three of the models. ELF is consistently negative but is never statistically significant. Among the religion variables, CATH80 and PROT80 enter positively, but with one exception, neither is ever statistically significant. MUS80 is always negative and is statistically significant in all but one model. Trade is always positive, but is only significant in 
one model. The $\mathrm{R}^{2}$ value in these specifications ranges from 0.77 to 0.83, suggesting that property rights institutions, geography, population heterogeneity and trade openness explain more than three-quarters of the variation in the level of economic development.

\section{B. Robustness}

Table 3 provides additional regression estimates indicating that the results obtained in table 2 are robust to the alternative control variables, strategic country sample restrictions, and the measure of GDP used. The results for each robustness check are reported in rows. The estimates hold constant the same set of control variables used in table 2 and, as before, the sample of countries is restricted to those for which data for all five measures of property rights are available.

Row 1 of table 3 replaces Coast with a dummy variable equal to one if a country is landlocked and zero otherwise. All five property rights measures remain strongly significant and the standardized coefficients increase relative to the baseline estimates from table 2, with the partial effect of ExecutiveConstraint remaining noticeably smaller than that of the other four measures.

Ashraf and Galor (2013a, p. 2) argue that genetic diversity of the contemporary population, which was shaped predominantly by human migration out of the "cradle of humankind in East Africa" tens of thousands of years ago, has both beneficial and detrimental effects on productivity. Their analysis suggests that the beneficial effects dominate at low levels of diversity where the role of heterogeneity contributes to a division of labor that expands society's production possibility frontier, but that there exists an optimal level of diversity, beyond which additional diversity leads to mistrust, reduced cooperation, and social disorder that acts to lower productivity and inhibit the economy's productive capacity. Ashraf and Galor (2013b) also argue that the cultural fractionalization is a function of genetic diversity. As such, controls for ancestry-adjusted genetic diversity and its square are included as an alternative to ELF in the results reported in row 2 of table 3 . ExecutiveConstraint remains positive but is not statistically significant in this specification. The other four measures remain statistically significant at the 1 percent level.

The countries of sub-Saharan Africa (SSA) remain among the most underdeveloped in the world. They also have relatively weak private property rights, as evidenced by mean property rights 
measures for the subsample of African nations that are two-thirds to three-quarters of a standard deviation lower than the mean for the full sample of countries. The results reported in row 3 of table 3 exclude the SSA nations to test whether significant disparities in the living standards between SSA and the rest of the world are driving the results. The resulting sample includes 68 countries. The magnitude of the standardized coefficients for the property rights measures is approximately 50 percent greater than the estimates obtained for the full sample of countries. Consistent with earlier results, all five property rights measures are positive and statistically significant at the 5 percent level or better, but ExecutiveConstraint has a weaker statistical and economic impact on GDP2010.

Nations transitioning from a communist to a more market oriented economy may exhibit moderately strong property rights and economic growth, but may remain less economically developed than nations with similar property rights protections that have had a market economy longer. Row 4 of table 3 excludes countries that the International Monetary Fund (2000) identified as transitioning economies in 2000, including former Soviet bloc countries and several Asian countries, such as China and Vietnam (International Monetary Fund 2000). The resulting estimates are similar to the analogous results reported in table 2 .

Table 3. Robustness Checks

\begin{tabular}{|c|c|c|c|c|c|}
\hline $\begin{array}{l}\text { Robustness } \\
\text { Test }\end{array}$ & $\begin{array}{l}\text { (1) } \\
\text { Expropriation } \\
\text { Risk }\end{array}$ & $\begin{array}{l}(2) \\
\text { Executive } \\
\text { Constraint }\end{array}$ & $\begin{array}{l}(3) \\
\text { Fraser } \\
\text { PRIndex }\end{array}$ & $\begin{array}{l}\text { (4) } \\
\text { Heritage } \\
\text { PRIndex }\end{array}$ & $\begin{array}{l}5) \\
\text { Rule } \\
\text { Law }\end{array}$ \\
\hline Control for & $0.63^{* * *}$ & $0.42^{* * *}$ & $0.56^{* * *}$ & $0.57 * * *$ & $0.62^{* * *}$ \\
\hline Landlocked & $(8.56)$ & $(3.74)$ & $(6.13)$ & $(7.95)$ & $(7.82)$ \\
\hline Control for & $0.50^{* * *}$ & 0.14 & $0.47^{* * *} *$ & $0.40^{* * *}$ & $0.46^{* * *}$ \\
\hline Gen. Diversity & $(4.49)$ & $(1.29)$ & $(4.43)$ & $(4.31)$ & $(4.74)$ \\
\hline Exclude & $0.79 * * *$ & $0.43^{* *}$ & $0.71^{* * *}$ & $0.67^{* * *} *$ & $0.73^{* * *}$ \\
\hline Africa Nations & $(6.67)$ & $(3.47)$ & $(4.69$ & $(5.78)$ & $(5.08)$ \\
\hline Exclude & $0.52 * * *$ & $0.25^{* *}$ & $0.38^{* * *}$ & $0.44^{* * *}$ & $0.45^{* * *}$ \\
\hline Transition & $(5.03)$ & 2.28 & $(3.56)$ & $(4.34)$ & $(4.32)$ \\
\hline Economies & & & & & \\
\hline Exclude & $0.48^{* * *}$ & $0.25^{*}$ & $0.32 * *$ & $0.38^{* * *}$ & $0.35^{* * *}$ \\
\hline OECD & $(4.57)$ & $(1.93)$ & $(2.61)$ & $(3.43)$ & $(2.84)$ \\
\hline Nations & & & & & \\
\hline PWT GDP & $0.52^{* * *}$ & $0.22 * *$ & $0.38^{* * *}$ & $0.33^{* * *}$ & $0.41 * * *$ \\
\hline Measures & $(5.57)$ & $(2.41)$ & $(4.60)$ & $(5.37)$ & $(-5.62)$ \\
\hline
\end{tabular}


Row 5 excludes the OECD countries from the sample. The mean of the five property rights measures among OECD nations is more than a standard deviation higher than the mean of the full sample, and most OECD nations are highly developed. Excluding the OECD countries tests the importance of property rights institutions for economic development in a sample of mainly low- and middleincome countries. The results are, again, similar, although the standardized coefficients for the property rights measures are marginally smaller when the OECD nations are excluded from the sample.

Ram and Ural (2014) point out differences between the Penn World Table (PWT) and World Development Indicators (WDI) GDP measures and advise researchers to test the sensitivity of their results to alternative measures of GDP. The main results reported in table 2 utilize the WDI measures. The results reported in row 6 of table 3 use the PWT 8.0 expenditure-side GDP2010 figures as the dependent variable (Feenstra, Inklaar, and Timmer 2013). The results pertaining to the property rights measures are relatively unchanged compared to the baseline estimates. ${ }^{22}$

\section{Concluding Remarks}

Economic theory suggests that institutions that protect private property are necessary for a market economy to function and to promote sustainable economic growth. A growing body of empirical evidence supports this. However, researchers continue to use a number of alternative measures of property rights. This paper assesses the methodology used to construct five of the most commonly used measures of property rights and tests their relative ability to predict the level of economic development in OLS regressions. The five measures are: the International Country Risk Guide risk of expropriation measure (ExpropriationRisk), the Polity IV executive constraints measure (ExecutiveConstraint), the Fraser Institute property rights index (FraserPRIndex), the Heritage

\footnotetext{
22 The results are similar using the PWT production-side GDP figures, as well as to the GDP measures from Baier, Dwyer, and Tamura (2006). We also ran regressions with GDP from 1995, 2000, and 2005, lagging the property rights variables accordingly, and found similar results. These results are omitted here but available in Bennett et al. (2015). We also tested the robustness of the estimates to the inclusion of a set of regional dummy variables. With one exception, none of the regional dummies was statistically significant in any specification, and including the dummy variables adds no explanatory power. These results are omitted but available upon request.
} 
Foundation property rights index (HeritagePRIndex), and the World Governance Indicator rule of law index (RuleLaw).

Each of the five measures has methodological strengths and weaknesses. The data underlying the ExecutiveConstraint, FraserPRIndex, and RuleLaw indicators are publicly available for researchers on the respective organizational websites, while the ExpropriationRisk measure data must be purchased. The ExecutiveConstraint measures are available annually as far back as 1800, making it most suitable for time series or long-run studies; however, it is at best a weak proxy for property rights. The FraserPRIndex data are available in five year increments since 1980 for a large number of countries, while the HeritagePRIndex and RuleLaw data are only available since 1995 and 1996, respectively. All three are therefore suitable for contemporary panel studies. RuleLaw, HeritagePRIndex, and ExecutiveConstraint provide measures for a larger number of countries than FraserPRIndex and ExpropriationRisk, but this may come at the expense of data objectivity. While all five measures are based to some extent on subjective data, the FraserPRIndex and RuleLaw measures rely on external assessments, while the ExpropriationRisk, ExecutiveConstraint, and HeritagePRIndex measures are based on opaque assessments by the respective organizations. The scoring assessment and aggregation method are highly transparent and easily replicable for FraserPRIndex and RuleLaw, but not for the other three measures. Researchers should be aware of these relative strengths and weaknesses when selecting an appropriate measure of property rights institutions.

In addition to the methodological strengths and weaknesses, researchers should also be aware of the relative ability of each of the five measures to predict the level of economic development. The empirical analysis in the current study provides guidance on this matter, reporting standardized coefficients from OLS regressions of real GDP per capita on each property rights measure and a set of control variables. While causality is difficult to empirically establish using OLS, there is good reason to believe that that correlations reported here reflect the causal impact of institutional protection of property rights on economic development. First, theory suggests that property rights are necessary to incentivize productive economic activity and to coordinate market activity, providing the conditions necessary for development. Second, the institutional measures represent a long-term average and are lagged relative to GDP to 
minimize the potential problem of endogeneity. Additionally, a number of studies have employed more advanced econometric techniques to provide evidence of the causal impact of property rights on economic development (Justesen 2014; Justesen and Kurrild-Klitgaard 2013; Rodrik, Subramanian, and Trebbi 2004).

The results indicate that ExpropriationRisk, FraserPRIndex, HeritagePRIndex, and RuleLaw exert a similar and both economically and statistically significant impact on economic development. A standard deviation increase in each of these four property rights measures is associated with a one-third to three-fourths standard deviation increase in economic development, all else equal. These results are robust to various sets of control variables, country sample restrictions, and alternative measures of GDP. Specifications using ExpropriationRisk, FraserPRIndex, HeritagePRIndex, or RuleLaw have considerable explanatory power, with most models predicting approximately three-fourths of the variation in the level of GDP per capita across a broad set of countries. These results provide additional evidence that institutional protection of private property is a robust determinant of economic development.

Meanwhile, ExecutiveConstraint exerts a weaker statistical and economic impact on economic development than the other measures of private property. It is also statistically insignificant in some specifications. ExecutiveConstraint purports to measure constraints on the political executive to arbitrarily extract property, but it does not provide information concerning constraints placed upon other governmental bodies or private actors. The analysis suggests that ExecutiveConstraint is a relatively poor proxy for institutional protection of private property rights and is not a robust determinant of economic development.

While the impact of institutions protective of private property rights on development is the main thrust of the current analysis, two other findings are noteworthy. First, the significance of the geography and climate variables is somewhat sensitive to the model specification and sample of countries, although each maintains the anticipated sign throughout the analysis. Second, neither genetic diversity nor its square is statistically significant, suggesting that genetic diversity may impact economic development through alternative channels such as institutional development, a hypothesis explored by Bennett et al. (2016). 


\section{References}

Acemoglu, Daron, and Simon Johnson. 2005. "Unbundling Institutions." Journal of Political Economy, 113(5): 949-95.

Acemoglu, Daron, Simon Johnson, and James A. Robinson. 2001. "The Colonial Origins of Comparative Development: An Empirical Investigation." American Economic Review, 91(5): 1369-1401.

Acemoglu, Daron, Simon Johnson, and James A. Robinson. 2005. "The Rise of Europe: Atlantic Trade, Institutional Change, and Economic Growth." American Economic Review, 95(3): 1231-94.

Acemoglu, Daron, Suresh Naidu, Pascual Restrepo, and James A. Robinson. 2014. "Democracy Does Cause Growth." NBER Working Paper 20004, Cambridge, MA: National Bureau of Economic Research.

Alesina, Alberto, Arnaud Devleeschauwer, William Easterly, Sergio Kurlat, and Romain Wacziarg. 2003. "Fractionalization." Journal of Economic Growth 8(2): 155-94.

Ashraf, Quamrul, and Oded Galor. 2013a. "The 'Out of Africa' Hypothesis, Human Genetic Diversity, and Comparative Economic Development." American Economic Review, 103(1): 1-46.

Ashraf, Quamrul, and Oded Galor. 2013b. "Genetic Diversity and the Origins of Cultural Fragmentation.” American Economic Review: Papers \& Proceedings, 103(3): 528-33.

Auer, Raphael A. 2013. "Geography, Institutions, and the Making of Comparative Development." Journal of Economic Growth, 18(2): 179-215.

Baier, Scott L., Gerald P. Dwyer, and Robert Tamura. 2006. "How Important Are Capital and Total Factor Productivity for Economic Growth?" Economic Inquiry, 44(1): 23-49.

Barro, Robert J. 1996. "Democracy and Growth." Journal of Economic Growth, 1(1): $1-27$.

Bennett, Daniel L., Hugo J. Faria, James D. Gwartney, and Daniel R. Morales. 2015. "Evaluating Alternative Measures of Institutional Protection of Property Rights and Their Relative Ability to Predict Economic Development." Working paper.

Bennett, Daniel L., Hugo J. Faria, James D. Gwartney, Hugo M. Montesinos-Yufa, Daniel R. Morales, and Carlos E. Navarro. 2016. "Economic Freedom vs. Executive Constraints: Casting Light on the Role of Economic and Political Institutions in Economic Development." Working paper.

Berggren, Niclas, Andreas Bergh, and Christian Bjørnskov. 2012. "The Growth Effects of Institutional Stability." Journal of Institutional Economics, 8(2): 187-224.

Easterly, William, and Ross Levine. 1997. "Africa's Growth Tragedy: Politics and Ethnic Divisions.” The Quarterly Journal of Economics, 112(4): 1203-50.

Easterly, William, and Ross Levine. 2003. "Tropics, Germs, and Crops: How Endowments Influence Economic Development.” Journal of Monetary Economics, 50(1): 3-39.

Faria, Hugo J., and Hugo M. Montesinos. 2009. "Does Economic Freedom Cause Prosperity? An IV Approach.” Public Choice, 141(1/2): 103-27.

Feenstra, Robert C., Robert Inklaar, and Marcel P. Timmer. 2013. "The Next Generation of the Penn World Table." Groningen, Netherlands: Groningen Growth and Development Center. 
Feld, Lars P., and Stefan Voigt. 2003. "Economic Growth and Judicial Independence: Cross-Country Evidence Using a New Set of Indicators." European Journal of Political Economy, 19(3): 497-527.

Gallup, John Luke, Jeffrey D. Sachs, and Andrew D. Mellinger. 1999. "Geography and Economic Development." International Regional Science Review, 22(2): 179_ 232.

Glaeser, Edward L., Rafael La Porta, Florencio Lopez-de-Silanes, and Andrei Shleifer. 2004. "Do Institutions Cause Growth?" Journal of Economic Growth, 9(3): 271-303.

Gwartney, James D., Randall G. Holcombe, and Robert A. Lawson. 2006. "Institutions and the Impact of Investment on Growth," Kyklos, 59(2): 255-73.

Gwartney, James, Robert Lawson, and Joshua Hall. 2013. Economic Freedom of the World 2013 Annual Report. Vancouver: Fraser Institute.

Hall, Joshua C., and Robert A. Lawson. 2014. "Economic Freedom of the World: An Accounting of the Literature." Contemporary Economic Policy, 32(1): 1-19.

Hall, Joshua C., Russel S. Sobel, and George R. Crowley. 2010. "Institutions, Capital, and Growth." Southern Economic Journal, 77(2): 385-405.

Hall, Robert E., and Charles I. Jones. 1999. "Why Do Some Countries Produce So Much More Output per Worker than Others?" Quarterly Journal of Economics, 114(1): 83-116.

International Monetary Fund. 2000. "Transition Economies: An IMF Perspective on Progress and Prospects." IMF Issue Briefs for 2000, Washington, DC: International Monetary Fund.

Justesen, Mogens K. 2014. "Better Safe Than Sorry: How Property Rights and Veto Players Jointly Affect Economic Growth.” Comparative Politics 46(2): 147_ 67.

Justesen, Mogens K., and Peter Kurrild-Klitgaard. 2013. "Institutional Interactions and Economic Growth: The Joint Effects of Property Rights, Veto Players and Democratic Capital." Public Choice, 157(3-4): 449-74.

Kaufmann, Daniel, Aart Kraay, and Massimo Mastruzzi. 2010. "The Worldwide Governance Indicators: A Summary of Methodology, Data and Analytical Issues." World Bank Policy Research Working Paper No. 5430, Washington, DC: World Bank.

Knack, Stephen, and Philip Keefer. 1995. "Institutions and Economic Performance: Cross-Country Tests Using Alternative Institutional Measures." Economics and Politics, 7(3): 207-27.

La Porta, Rafael, Florencio Lopez-de-Silanes, Andrei Shleifer, and Robert W. Vishny. 1999. "The Quality of Government." Journal of Law, Economics and Organization, 15(1): 222-79.

Langbein, Laura, and Stephen Knack. 2010. "The Worldwide Governance Indicators: Six, One, or None?” Journal of Development Studies, 46(2): 350-70.

Marshall, Monty G., Ted Robert Gurr, and Keith Jaggers. 2013. Polity IV Project: Political Regime Characteristics and Transitions: 1800-2012. Vienna, VA: Center for Systemic Peace.

Miller, Terry, Anthony B. Kim, and Kim R. Holmes. 2014. 2014 Index of Economic Freedom. Heritage Foundation and Wall Street Journal.

Munck, Gerardo L., and Jay Verkuilen. 2002. "Conceptualizing and Measuring Democracy: Evaluating Alternative Indices." Comparative Political Studies, 35(5): $5-34$. 
North, Douglass. 1990. Institutions, Institutional Change and Economic Performance. Cambridge, UK: Cambridge University Press.

Paldam, Martin, and Erich Gundlach. 2008. "Two Views on Institutions and Development: The Grand Transition vs the Primacy of Institutions." Kyklos 61(1): 65-100.

Persson, Torsten, and Guido Tabellini. 2003. The Economic Effects of Constitutions: What do the Data Say? Cambridge, MA: MIT Press.

Ram, Rati, and Secil Ural. 2014. "Comparison of GDP per Capita Data in Penn World Table and World Development Indicators." Social Indicators Research, 116(2): 639-46.

Rodrik, Dani. 2000. "Institutions for High-Quality Growth: What They Are and How to Acquire Them." Studies in Comparative International Development, 35(3): 331.

Rodrik, Dani, Arvind Subramanian, and Francesco Trebbi. 2004. "Institutions Rule: The Primacy of Institutions over Geography and Integration in Economic Development." Journal of Economic Growth, 9(2): 131-65.

Sachs, Jeffrey D. 2003. "Institutions Don't Rule: Direct Effects of Geography on Per Capita Income.” NBER Working Paper 9490, Cambridge, MA: National Bureau of Economic Research.

Sachs, Jeffrey D., and Andrew Warner. 1995. "Economic Reform and the Process of Global Integration. Brookings Papers on Economic Activity, 1: 1-118.

Sala-i-Martin, Xavier, Gernot Doppelhofer, and Robald I. Miller. 2004. "Determinants of Long-Term Growth: A Bayesian Averaging of Classical Estimates (BACE) Approach.” American Economic Review, 94(4): 813-35.

Thomas, M. A. 2010. "What Do the Worldwide Governance Indicators Measure?" European Journal of Development Research, 22(1): 31-54.

Voigt, Stefan. 2012. "How to Measure the Rule of Law." KYKLOS, 65(2): 262-84.

Voigt, Stefan. 2013. "How (Not) to Measure Institutions." Journal of Institutional Economics, 9(1): 1-26.

Voigt, Stefan, and Jerg Gutmann. 2013. “Turning Cheap Talk into Economic Growth: On the Relationship between Property Rights and Judicial Independence." Journal of Comparative Economics, 41(1): 66-73.

Wacziarg, Romain, and Karen H. Welch. 2008. "Trade Liberalization and Growth: New Evidence.” World Bank Economic Review, 22(2): 187-231. 